\title{
Prós e Contras: o debate político televisivo como sub-género/sub-tipo de interaç̧ão verbal
}

\author{
Daniela Braga \\ Universidade da Coruña
}

\begin{abstract}
Resumo:
Neste artigo, temos como objectivo caracterizar a especificidade do debate político televisivo enquanto sub-género/sub-tipo de interacção verbal, numa perspectiva interaccionista, a partir da descrição do funcionamento do seu quadro comunicativo. Pretendemos também sublinhar que a sua natureza política conduz ao discurso polémico, espaço de argumentação e dialogismo.
\end{abstract}

\section{Palabras chave:}

Género, tipo, debate político televisivo, interacção verbal, quadro comunicativo, quadro părticipativo, discurso político, discurso polémico.

\begin{abstract}
:
In this paper, we intend to define the television political debate as a sub-gender/sub-type of verbal interaction, from an interactionist theoretical perspective, by describing the function of its communication framework. Our purpose is also to highlight that the political nature of this verbal interaction type leads to the polemic discourse, where argumentation and dialogism take place.
\end{abstract}

Key words:

Gender, type, television political debate, verbal interaction, communication framework, participation framework, political discourse, polemic discourse.

\section{Problemática da tipologização dos discursos}

L'une des raisons qui fait que la linguistique ignore les formes d'énoncés tient à l'extrême hétérogénéité de leur structure compositionnelle et aux particularités de leur volume (la longueur du discours) - qui va de la réplique monoléxematique au roman en plusieurs tomes.

(Bakhtine 1984: 288) [itálico nosso]

Le débat représente aujourd'hui avec sa variante du face-à-face télévisé la version moderne du tournoi chevaleresque où tous les coups ne sont pas permis en raison d'un code de courtoisie.

(Vion 1992: 126). 
A problemática da tipologização dos discursos tem sido um dos assuntos mais debatidos e polémicos em Linguística do Texto/Discurso, tendo dado origem a inúmeras propostas de classificação.

Aparentemente, e como sublinha Sarfati (1997: 75), a tarefa da tipologização parece ser um problema irresolúvel, por duas razões: em primeiro lugar, pelo carácter fluido, indeterminado, transitório dos textos/discursos ${ }^{1}$, e em segundo lugar, pela profunda dependência contextual subjacente a todos os discursos, o que lhes impõe restrições na produção e no sentido dos enunciados.

Marques (2003: 194), a propósito da "instabilidade dos géneros", reforça essa dependência contextual (socio-histórica, cultural, temporal) como estando na base da "cristalização temporária" dos géneros por um dado grupo social/linguístico:

(...) ao definir um género de discurso como a configuração de escolhas que se cristalizam progressivamente no quadro de um grupo social/ linguístico dado, o entendemos como cristalização temporária. Porque a instabilidade dos géneros, produto socio-histórico, é factor e ao mesmo tempo consequência da mudança. (...) E desta forma, a variabilidade social e cultural, a mudança em geral que se opera nas sociedades fará necessariamente emergir novas formas, mesmo novos géneros, onde os discursos ganharão também novas configurações.

A intrínseca "heterogeneidade composicional dos enunciados" de que fala Baktine (1984: 288), no excerto em epígrafe, está na base da dificuldade que nos surgiu para a definição de debate político televisivo em termos de género ou tipo. $\mathrm{O}$ uso lexicográfico da língua já atestou a sua existência enquanto unidade distinta de outras, mas em Linguística do Uso/Funcionamento da Língua ${ }^{2}$ a sua caracterização começa pela questão da pertença a um género ou um tipo de discurso.

Marques (2003: 190-193) apresenta uma síntese das noções que têm estado associadas aos termos tipo e género em análise do discurso. A noção de género tem larga tradição na história da literatura, mas é Bakhtine que primeiro faz referência a uma

1 Apesar da enorme flutuação entre as designações de Texto e Discurso na literatura da especialidade, entendemos Texto como equivalente a Discurso, de acordo com a proposta de Fonseca (1992) que se refere a esta entidade como Texto/Discurso. Marques (2003: 190), por exemplo, opta pela designação de Discurso, que não diferencia de Texto. Para uma discussão mais aprofundada da disputa terminológica entre Texto e Discurso em Análise do Discurso, confrontar Marques (2000: 57-58).

2 Expressão de Fonseca (1994: 13). O autor opõe dois paradigmas: a Linguística do Uso/Funcionamento da Língua (actualizada pelas recentes orientações em Pragmática e Análise do Discurso, centradas sobre o uso da língua real) vs a Linguística do Sistema (consubstanciada pelas correntes estruturalistas e generativistas, mais centradas no funcionamento teórico das línguas, na criação de modelos nem sempre coincidentes com a performance real das línguas). 
matriz de géneros, um "pressentimento" 3 que cada um possui, que permite desde o início perceber o género do discurso em causa. Assim, género tem sido erradamente apresentado como uma classificação externa, estando os critérios da sua definição relacionados com a situação discursiva (modo de transmissão, interlocutores, contexto linguístico-social e intertextual e intenção do falante). Por outro lado tipo tem estado ligado a uma classificação interna, a partir da arquitectura interna do discurso. Progressivamente os géneros foram preteridos em relação aos tipos, alegando-se a exterioridade do género em relação ao texto. Inúmeras são as propostas tipológicas ${ }^{4}$ para os discursos e a flutuação entre género e tipo tem sido verificada pelo mesmo autor. Por exemplo, Adam $(1992,1996)$ fala de tipos, em momentos diferentes da sua carreira, vindo a falar mais tarde de "géneros epistolares" (Adam 1998).

Mas mais do que decidir sobre a classificação do debate político televisivo enquanto tipo ou género, parece-nos evidente que o debate político televisivo é uma categoria discursiva suficientemente específica e delimitável, com uma estrutura e funcionamento particulares, como passaremos a descrever em seguida.

\section{Em torno da definição de debate}

Apesar de o debate televisivo ser uma dimensão tida em consideração para as Ciências da Comunicação, é porém, no domínio da Análise do Discurso e especialmente no campo da Análise Conversacional que se encontram os estudos mais relevantes para a definição do debate televisivo. É, igualmente, no mesmo campo de estudos que é possível encontrar uma correlação entre o género debate e os estudos em argumentação.

Entre os principais estudos acerca do estatuto teórico do debate em Pragmática e Análise do Discurso, salientam-se os de Kerbrat-Orecchioni (1990) e os de Vion (1992). Serviu também de base ao nosso trabalho a aplicação prática desses estudos levada a cabo por Doury, que introduz, desde logo, o debate televisivo como um género: "Nous nous proposons d'analyser une interaction relevant du genre "débat télévisé» et de définir aussi précisément que possible système d'interlocution qu'elle met en jeu" (Doury 1995: 224) [itálicos nossos].

3 Sobre este assunto, veja-se o seguinte excerto de Bakhtine (1984: 285): “Nous apprenons à mouler notre parole dans les formes du genre et, entendant la parole d'autrui, nous savons d'emblée aux tout premiers mots, en pressentir le genre, en deviner le volume (la longueur approximative d'un tout discursive), la structure compositionnelle donnée, en prévoir la fin, autrement dit, dès le début, nous sommes sensibles au tout discursif qui, ensuite, dans le processus de la parole dévidera ses différenciations. Si les genres du discours n'existaient pas et si nous n'en avions pas la maîtrise, (...) l'échange verbal serait quasiment impossible" [itálicos nossos].

4 Para uma revisão crítica acerca das tipologias de tipologias, veja-se Fuentes (2000: 121) e Coutinho (2003: 59). 
É também interessante a concepção de debate televisivo desenvolvida por Charadeau/Ghiglione (1997: 55-68), retomada em Pires (2002). Esta autora destaca da teoria de Charadeau/Ghiglione a dimensão de "dupla encenação: verbal e visual" inerente ao debate televisivo, sendo a encenação verbal a que mais interessa à autora "com a certeza de que lhe estão associadas estratégias que se aproximam muito dos pressupostos inerentes à teoria da argumentação (...)" (Pires 2002: 12). Dentro deste quadro teórico, a autora destaca como objectivos e fins subjacentes à "encenação verbal": 1) a posse da palavra, desencadeando apropriações indevidas da palavra, intrusões frequentes e tentativas de manutenção da palavra; 2) influência, através da qual os participantes no debate determinam entre si relações de conflito, coligação, aliança ou rejeição; 3) verdade, através da qual "os participantes são obrigados a posicionar-se em relação ao que pensam ser verdadeiro ou falso, a tomar partido, a impor mesmo o seu modelo de pensamento, os seus valores, as suas opiniões (Pires 2002: 11).

Kerbrat-Orecchioni (1990), na sua investigação sobre as interacções verbais, considera e caracteriza o debate como um tipo de interacção verbal oral, ao lado da conversação, da discussão, do "entretien" e da entrevista. Orecchioni define interacção verbal enquanto troca comunicativa entre dois participantes que exercem influências recíprocas uns sobre os outros:

tout au long du déroulement d'un échange communicatif quelconque, les différents participants, que l'on dira donc des «interactants», exercent les uns sur les autres un réseau d'influences mutuelles - parler, c'est échanger, et c'est changer en échangeant (Kerbrat-Orecchioni 1990: 17).

Estes "interactantes" realizam um conjunto de acções/sinais verbais e para-verbais (prosódicos, cinésicos e proxémicos) que funcionam como "validação interlocutória", ou seja, que atestam o seu envolvimento mútuo na troca comunicativa e asseguram a sua gestão:

Pour qu'il y ait échange communicatif, il ne suffit pas que deux locuteurs (ou plus) parlent alternativement; encore faut-il qu'ils se parlent, c'est-à-dire qu'ils soient tous deux «engagés» dans l'échange, et qu'ils produisent des signes de cet engagement mutuel, en recourant à divers procédés de validation interlocutoire (...) (Kerbrat-Orecchioni 1990: 18)

Numa nota, Kerbrat-Orecchioni (1990: 124) explica que lhe interessam as interacções orais pelo seu carácter imediato e produzido em presença (embora note a existência de formas dialogadas em produções escritas e autênticas), por oposição aos diálogos fabricados pertencentes a universos ficcionais. 
Ainda segundo Orecchioni, enquanto interacção específica, o debate é, portanto, uma discussão $o^{5}$ em que se verifica um confronto de opiniões, mas que possui um carácter mais organizado, desenrolando-se dentro de um quadro "pré-fixado", ou seja, o seu quadro comunicativo, cuja descrição faremos mais adiante, e em que algumas coordenadas são pré-determinadas. A presença de um moderador e de um público completam o quadro participativo e contribuem para a especificidade do debate dentro da tipologia de interacções verbais proposta pela autora:

le débat est une discussion plus organisée, moins informelle: il s'agit encore d'une confrontation d'opinions à propos d'un objecte particulier, mais qui se déroule dans un cadre "préfixé » (...) - sont ainsi en partie déterminés la longueur du débat, la durée et l'ordre des interventions, le nombre de participants, et le thème de l'échange. En outre, un débat comporte généralement un public, et un « modérateur » chargé de veiller à son bon déroulement (et même en leur absence, on peut dire que ce modérateur et ce public sont en quelque sorte intériorisés par les participants). Le débat tient donc à la fois de la discussion (par son caractère argumentatif), et de l'interview (par son caractère médiatique) (Kerbrat-Orecchioni 1990: 118) [itálicos nossos].

O debate distingue-se também da entrevista em virtude da dissimetria existente entre os papéis interaccionais do entrevistador e do entrevistado (KerbratOrecchioni 1990: 119-120), o que não se pode verificar no debate, em que os dois participantes devem ocupar papéis equilibrados e semelhantes, embora significativamente menos controladores quando comparados com o papel do moderador. É, igualmente, importante ressaltar da definição proposta por Orecchioni o carácter argumentativo e o carácter mediático que o debate partilha respectivamente com a discussão e com a entrevista e que contribuem para a sua heterogeneidade discursiva. Finalmente, a autora sugere que o debate funciona como um modelo de conversação ${ }^{6}$, por ser uma interacção eficaz e disciplinada, exemplo da boa aplicação das regras conversacionais (Kerbrat-Orecchioni, 1990: 119).

5 Kerbrat-Orecchioni define discussão como "cas particulier de conversation" que tem como especificidade "comporter une composante argumentative importante: [...] convaincre les uns les autres" e que a aproxima do debate. A autora destaca ainda a sua dimensão agónica e conflitual (Kerbrat-Orecchioni 1990: 118).

6 Kerbrat-Orecchioni (1990 : 115) define conversação como o tipo mais prototípico de interacção verbal : "la conversation est unanimement reconnue comme représentant le prototype de toute interaction". Na caracterização deste tipo específico de interacção verbal, Kerbrat-Orecchioni (1990: 114115). identifica algumas propriedades: 1) carácter imediato, no tempo e no espaço (proximidade dos participantes, contacto directo, resposta instantânea...); 2) carácter familiar (ou não formal), espontâneo, improvisado, descontraído e opõe-se a outras formas que têm as suas componentes fixadas à partida, como número de participantes, temas tratados, duração das intervenções e das réplicas, alternância de vezes; 3) carácter gratuito e não finalizado, sem fim instrumental, em que se fala por falar, por prazer, por jogo ou por delicadeza; 4) carácter igualitário: os participantes possuem os mesmos direitos e deveres independentemente do estatuto que possuam. 
Vion (1992), dois anos depois, apresenta uma tipologia com mais tipos de interacções verbais inventariados segundo critérios diferentes daqueles propostos por Orecchioni ${ }^{7}$. Como consequência, insere no grupo das interacções complementares a consulta, o inquérito, o entretien e a transacção, enquanto que o debate é integrado no âmbito das interacções simétricas ${ }^{8}$, ao lado da conversação, da discussão e da disputa. O debate é analisado evocando permanentes isotopias com o domínio da competição desportiva, do duelo ou do torneio, como sugere a citação em epígrafe e a que se segue, em que também são enunciados os participantes no debate:

le débat est le lieu de tous les dangers et, apparemment les deux protagonistes occupent des places comparables et peuvent également prétendre l'emporter. Il existe même une sorte de code d'honneur qui permet d'apparenter le débat au duel ou au tournoi (Vion 1992: 138) [itálicos nossos].

C'est l'existence du public qui conditionne cette interaction et rend possible la comparaison métaphorique avec le match. Le caractère formel sera accentué par la présence d'arbitre(s) pour veiller au bon déroulement du «combat» (Vion 1992 : 139) [itálicos nossos].

À semelhança das competições desportivas, também no debate há vencedores e vencidos, embora, como refere o autor, os ganhos sejam simbólicos, não traduzíveis em termos de acção (Vion 1992: 127). Os ganhos consistem basicamente em ser-se bem sucedido na persuasão ou no convencimento do público, elemento não participante mas fundamental na composição do quadro comunicativo do debate, funcionando como objectivo final neste tipo de interacção. Mais uma vez, à semelhança dos torneios, o debate tem regras, possui uma espécie de código que consiste em jogar/cooperar de modo competitivo. Vion destaca também o carácter formal do debate devido à presença de uma entidade a que chama isotopicamente "árbitro", que vela pelo bom desenrolar do "combate" e que "effectue les rituels d'ouverture, énonce les thèmes et l'ordre dans lequel ils vont être abordés, rappelle les

7 Para Kerbrat-Orecchioni (1990: 124-129), os critérios subjacentes à distinção operada entre os tipos de interacções verbais são: natureza da situação (quadro espácio-temporal), número e natureza dos participantes em relação com o seu estatuto participativo (uma conferência opõe-se ao debate na medida em que este pode comportar um número significativo de participantes igualmente activos, ao contrário da outra), objectivo da interacção (há interacções com propósito de consolar, seduzir, convencer, como a discussão e o debate), grau de formalidade, estilo ou tom (sério vs lúdico; consensual vs conflituoso), duração da interacção ou ritmo e o seu conteúdo. Vion (1992: 124-129) apresenta uma tipologia de interacções verbais construída segundo quatro critérios: relações de simetria/complementaridade, relações de cooperação/competição, finalidade das interacções e carácter formal/informal das interacções.

8 Vion (1992: 124) serve-se dos trabalhos da escola de Palo Alto para especificar a natureza destes dois tipos de interacção. Assim, nas relações complementares um dos participantes ocupa uma posição superior e o outro inferior (por exemplo, as interacções mãe-filho, médico-paciente, professor-aluno). Nas relações simétricas, verifica-se um comportamento em espelho, em que os participantes possuem estatutos semelhantes. 
règles, distribue la parole, veille au respect du temps de parole de chacun et peut s'intercaler entre les belligérants." (Vion 1992 : 139).

Tal como num combate, Vion chama a atenção para o factor do perigo subjacente ao debate, visível na possibilidade de o seu resultado final poder ser decidido em poucos segundos, a lembrar o knock-out técnico do combate.

Vion (1992: 123-124) admite, também, que as interacções podem ser unilaterais sendo que a base interaccional decorre do dialogismo interno ao texto, distinguindo assim "interacções sem estrutura de échange" ou troca verbal (como as produções literárias, jornalísticas, conferências, cartazes) de "interacções com estrutura de échange" (como correspondência epistolar, diálogos radiofónicos ou televisivos, relações interpessoais e comunicação entre grupos).

Em síntese, parece-nos importante destacar das propostas conduzidas por Orecchioni e Vion os seguintes aspectos que podem definir o tipo de interacção verbal especializada que é o debate:

- a existência de um "quadro participativo" triangular, de que fazem parte pelo menos dois participantes, um moderador e um público;

- o papel fundamental do moderador para a regulação e estruturação do debate e das intervenções dos participantes;

- os papéis equilibrados, simétricos, equifuncionais dos participantes no debate;

- a importância do público em função do qual os participantes constroem a sua argumentação com vista à persuasão (isotopicamente com vista à vitória);

- o carácter pré-fixado e formal a que obedece o debate, em que estão à partida decididos o tema e a duração do debate, a ordem de intervenções, o número de participantes;

- a forte componente argumentativa, que funciona como arma verbal;

- a sua natureza dialogal, que assegura a sua especialização como um tipo de interacção verbal.

\section{O quadro comunicativo do debate}

A caracterização de qualquer género discursivo é indissociável da dimensão do contexto em que se inscreve, noção tão flutuante como fundamental em Pragmática e Análise do Discurso. Como observa Kerbrat-Orecchioni (1990: 75-76), é com a Pragmática que o estatuto do contexto é reabilitado dentro do panorama linguísti- 
co, devido à constatação da sua importância para a determinação das operações de produção e de interpretação dos enunciados.

Sendo, portanto, as propriedades do contexto responsáveis pela individualização e especificação de cada texto/discurso dentro do seu género, a sua caracterização torna-se assim fundamental para a descrição desse mesmo texto/discurso. Por outras palavras, a descrição e análise do debate televisivo Prós e Contras deve ser feita em função das suas coordenadas contextuais, ou na expressão de KerbratOrecchioni, do seu quadro comunicativo. Partindo do modelo de comunicação proposto por Brown/Fraser (1979), Kerbrat-Orecchioni (Kerbrat-Orecchioni 1990: 76-81) apresenta a sua definição de contexto inserido no âmbito do que designa por "quadro comunicativo":

Du fait sans doute qu'elle a été trop longuement 'négligée' et considérée par les linguistes comme marginale, la notion de «contexte», ou de «situation», les deux termes étant ici équivalents (...) nous entendons par «contexte»l'environnement extralinguistique de l'énoncé, par opposition au «cotexte» linguistique, cette notion est donc loin d'avoir un statut clair (...) je m'inspirerai ici plutôt du modèle proposé par Brown et Fraser (1979), qui décomposent la situation de la façon suivante, en ce qui concerne ses composantes générales:

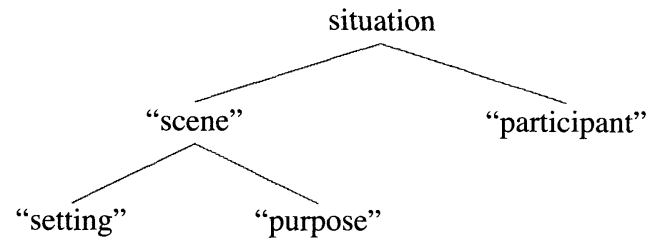

(1) Le site ('setting'): c'est le cadre spatio-temporel. (...)

(2) Le but ('purpose'). (...) le but est dans une certaine mesure intégré au site, puisqu'à tout site est associée une finalité intrinsèque. (...)

(3) Les participants (leur nombre et leur nature). C'est évidemment l'aspect le plus important du cadre communicatif. Les participants peuvent être envisagés dans leurs caractéristiques individuelles, biologiques et physiques (âge, sexe, appartenance ethnique, et autres propriétés de l'être et du parầtre), sociales (profession, statut, etc.), et psychologiques (constantes et passagères: caractère et humeur); ou dans leurs relations mutuelles, degré de connaissance, nature du lien social (familial ou professionnel, avec ou sans hiérarchie), et affectif (sympathie ou antipathie, amitié, amour, et autres sentiments qui peuvent être ou non partagés) [itálicos nossos]

O quadro comunicativo de uma interacção verbal compreende assim três componentes: o quadro espácio-temporal, o objectivo e os participantes, sendo efectiva- 
mente esta última componente a mais relevante das coordenadas do quadro comunicativo, já que no seu conjunto formam o "quadro participativo".

\title{
4. O quadro participativo do debate
}

O aspecto mais importante para a caracterização do debate televisivo é a composição do seu quadro participativo. Orecchioni recuperou o conceito de "participation framework" de Goffman (1981), traduzindo-o por "quadro participativo" (Kerbrat-Orecchioni 1990: 83), designando o número de participantes e o seu estatuto interlocutivo. Os participantes de uma interacção podem ser igualmente locutores e ouvintes potenciais. Kerbrat-Orecchioni (1990: 83) faz referência à distinção de Goffman entre os participantes ratificados, aqueles que estão "véritablement intégrés au groupe conversationnel, et que produisent certains signes de leur engagement dans l'interaction en cours", e os "bystanders", aqueles que apenas assistem à interacção verbal mas que estão de fora dela.

Doury (1995: 227) resume que o debate põe em jogo quatro "entidades": pelo menos dois participantes ou "débateurs", um moderador e um público, permitindolhe considerar o debate como um tipo de trilogue 9 . Pela estrutura triádica do debate, em termos de número mínimo de actores intervenientes no quadro participativo,

\author{
Moderador + público \\ "Débateur" 1 "Débateur" 2
}

Figura 1: Esquema do trílogo que compõe o quadro participativo do debate televisivo.

Doury (1995) conclui que se trata de um trílogo, no quadro teórico de análise das interacções verbais proposto por Orecchioni, na medida em que interagem dois "débateurs"(adversários) e o público ao lado do moderador, o qual funciona como porta-voz ${ }^{10}$ desse público (veja-se a Figura 1).

9 Na sequência da proposta de Kerbrat-Orecchioni (1995) de definição alargada de diálogo, surgiram os neologismos dílogo, trílogo e polílogo ("dilogue", "trilogue" e "polylogue") em função do número de locutores envolvidos na interacção verbal. O "trilogue" é então uma forma particular de diálogo onde intervêm três locutores.

${ }^{10}$ Além de Bourdieu, a ideia do moderador como porta-voz do público silencioso é recuperada de Denis (1988: 84) por Doury: '[...] l'animateur fonctionne comme relais du public, à qui il tient lieu de porteparole" [itálico nosso]. 


\subsection{O moderador}

O moderador, pelo seu papel fundamental dentro do quadro participativo, é alvo de destaque especial pela parte de Kerbrat-Orecchioni (1990: 84). O moderador é, assim, um tipo de participante particular, encarregado de gerir a organização das tomadas de vez nos debates mediáticos ou nos colóquios, podendo ocasionalmente assumir o papel de participante regular:

Certains rôles participatifs particuliers sont propres à certains types particuliers d'interactions, comme celui du «modérateur», chargé de gérer l'organisation des tours de parole dans les débats médiatiques, ou les colloques (...) (Kerbrat-Orecchioni 1990: 84)

Portanto, o "actor" mais importante presente no debate televisivo é o moderador, "instance régulatrice exterieure" (Doury 1995: 231), a quem são atribuídas as seguintes responsabilidades:

- a condução e o bom desenrolar do tema do debate;

- a referência às regras de emissão do programa;

- a alternância de vez e gestão dos tempos concedidos aos participantes;

- a concessão ou retirada da palavra;

- a suavização dos ânimos sempre que estes se alterem ("qui mantienne la polémique dans certains limites (...), empêche que l'interaction ne dégénère en pugilat"( Doury 1995: 231) ;

- o ajuste entre os conhecimentos dos participantes e os do público, no sentido de tornar acessível o conteúdo do debate ao maior número de telespectadores;

- a defesa dos interesses informativos do público não presente ("fasse en sorte que l'intérêt du tiers absent soit respecté" (Doury 1995 : 231).

Apesar de o moderador dispor de menos tempo de posse da palavra, Doury (1995: 246) conclui que o seu papel dominante se reflecte na produção exclusiva das sequências de abertura e conclusão do debate, na exclusividade (teórica) da formulação das perguntas (é ele quem põe as questões aos convidados), no reconhecimento da sua autoridade pelos participantes porque "c'est lui le «maître du jeu», le dépositaire des règles générales qui régissent les débats télévisés”.

Outra das funções, a de porta-voz do público, é visível, como observa Doury (1995: 246-247), nas sequências em que o moderador exige uma reformulação dos conteúdos com objectivo de ajustar os conhecimentos do público e dos participantes, ou nas sequências em que o moderador faz uma síntese avaliativa ou judi- 
cativa sobre os conteúdos enunciados pelos participantes ou sobre o próprio curso do debate.

Apesar da esperada e estereotipada imagem de imparcialidade ${ }^{11}$ por parte do moderador, o enorme poder que detém no quadro participativo do debate e a sua condição de Locutor Ser do Mundo reflectem-se no uso que faz da palavra, poucas vezes neutral ${ }^{12}$, frequentemente carregada de subjectividade.

\title{
4.2. Os participantes no debate ou "débateurs"
}

Kerbrat-Orecchioni não se refere em particular ao estatuto dos "débateurs", na expressão de Doury, mas define o conceito de participante como uma entidade verdadeiramente integrada num grupo conversacional e que, por isso, manifesta sinais do seu envolvimento na interacção em curso (Kerbrat-Orecchioni 1990: 83). Refere ainda a rotatividade de papéis de "locutor" e de "ouvinte" que cada participante experimenta, típicos da conversação:

\begin{abstract}
Ainsi toute conversation met-elle en présence des participants qui ont également le statut de locuteurs et d'auditeurs potentiels; mais c'est l'un d'entre eux seulement qui va en un temps T occuper la position émettrice (KerbratOrecchioni 1990:84) [itálicos nossos]
\end{abstract}

Ao tomar a palavra, cada participante institui-se como locutor, convocando vozes ou enunciadores que usa estrategicamente para a construção do seu ethos $^{13}$ ou imagem pessoal. Desta forma, o locutor constrói o seu "quadro de locução". Mas ao instituir-se como locutor, institui também perante si alocutários ou um "quadro de alocução", na expressão de Marques (2000: 243). As vozes de cada participante do

11 Doury (1995: 231), no seu estudo, inscreve moderador do Duel sur la Cinq dentro de um estereótipo "conforme à ideologia da neutralidade", na sua expressão: “sa fonction d'animateur veut qu'il s'éfface au maximum". Doury (1995: 232) refere, no entanto, que existe outra imagem de moderador que é cultivada por outros programas, o moderador que cultiva a insolência, a irreverência.

${ }^{12}$ A falta de neutralidade ou a subjectividade intrínseca que percorre os discursos é visível em enunciados como o seguinte, em que a moderadora do nosso debate em análise não consegue evitar a ironia:

RR: [...] as autarquias não são uma ilha na admnistração pública portuguesa (,)(‘) fazem parte de um todo XXX

FCF: eu diria que são um grande arquipélago (..)(')(!)

${ }^{13}$ Ethos é um conceito da Retórica de Aristóteles que foi recuperado pela Análise do Discurso e que significa a imagem que o Locutor constrói de si mesmo no discurso e que se reflecte nos meios de expressão da subjectividade da linguagem e da modalidade. Ducrot (1984: 200-201) recupera a noção de ethos no quadro da teoria polifónica. Para Ducrot, ethos decorre do discurso do Locutor L e não orador $\lambda$, ser do mundo. Amossy (2000: capítulo 2) faz uma história dos vários desenvolvimentos que a noção de ethos sofreu desde a antiguidade clássica e apresenta uma proposta de distinção entre "ethos préalable" ou ethos anterior (imagem pré-existente que o auditório possui sobre o Locutor) e ethos discursivo (imagem que o locutor constrói no seu discurso). 
debate estilhaçam-se em outras vozes que contribuem para a imagem linguística que cada participante constrói de si mesmo.

\subsubsection{O Quadro da Locução}

Kerbrat-Orecchioni (1999: 25-27) analisa as instâncias do "emissor" e do "receptor" à luz da teoria da enunciação ${ }^{14}$. Para a autora, trata-se de instâncias demasiado complexas, que se multiplicam em diversas vozes de locução e alocução. O pólo da locução, enquanto coordenada fundamental do "dispositivo formal da enunciação", na expressão de Benveniste (1970), é assegurado, na superfície discursiva, pela deixis pessoal da primeira pessoa, que se organiza em torno dos pronomes pessoais EU/NÓS, embora, obviamente, não se restrinja a estes, como nota Marques (2000: 175-176):

Uma taxonomia dos pronomes que realizam a referência pessoal assenta, basicamente, no subsistema dos pronomes pessoais, mas não se limita a estes. É, pois, necessário incluir todas as formas de pronomes pessoais (não apenas as formas de nominativo) e também os possessivos, os demonstrativos e mesmo os indefinidos. [...] A par dos pronomes [...] a marcação linguística das "pessoas", a sua nomeação, pode ser feita por mecanismos morfológicos de flexão verbal, ou ainda, por construções léxico-gramaticais (Marques 2000: 175-176) [itálicos nossos].

Considerando a distinção entre locutor ser do mundo $(\lambda)$ e locutor responsável pelo enunciado (L) ${ }^{15}$, operada por O. Ducrot no quadro da Teoria Polifónica, a definição

${ }^{14}$ Kerbrat-Orecchioni (1990) baseia o seu trabalho no conceito de enunciação tal como ele foi definido primeiramente por Benveniste (1970) e mais tarde por Anscombre/Ducrot (1970, 1976). Benveniste define assim enunciação: "L'énonciation est cette mise en fonctionnement de la langue par un acte individuel d'utilisation.” (Benveniste 1970: 12). O conceito de enunciação é central em Análise do Discurso sendo, como afirma Marques (2000: 69), "captado nas marcas que deixa na superfície textual", ou seja, nas marcas linguísticas que assinalam as coordenadas do EU/TU - AQUI - AGORA. Desta forma, a alteridade, resultante da inscrição do eixo EU-TU na linguagem, "integra em si a natureza interaccional da linguagem" (Marques 2000: 70), de que pode ser exemplo o debate televisivo.

15 Ainda no enquadramento da Teoria Polifónica de Ducrot, entendemos os conceitos de Locutor e Alocutário como entidades simétricas, colocadas num primeiro plano da enunciação. O Locutor é o responsável pelo enunciado que produz "un être qui, dans le sens même de l'énoncé, est présenté comme son responsable" (Ducrot 1984 :193) e distingue-se do sujeito falante ou ser do mundo $(\lambda)$ tal como o narrador se distingue do autor em Narratologia: "[le locuteur] parle au sens où le narrateur raconte" (Ducrot 1982: 74, 76). O Alocutário é a instância a quem o Locutor dirige o enunciado ("l'être à qui les paroles sont dites" (Ducrot 1980: 43). Distingue-se também do Ouvinte empírico, à semelhança da diferenciação operada entre Autor/Locutor. No entanto, e como observa Marques (que faz uma apresentação exaustiva sobre as vozes envolvidas na teoria polifónica de Ducrot (Marques 2000: Cap. 2), "o alocutário é, nos desenvolvimentos teóricos de Ducrot, uma entidade linguística muito mais indefinida, menos abordada e discutida nas suas funções e relações" (Marques 2000: 97). 
do locutor torna-se mais complexa sobretudo pela dificuldade de identificação do seu referente, como observa Marques (2000: 176). No seu estudo sobre o funcionamento do debate político parlamentar, Marques (2000: Capítulo 4) mostra como as várias ocorrências dos pronomes EU e NÓS estabelecem na realidade uma rede de referências muito complexa (que pode ser Nós = interlocutores colectivos, Nós = vox populi, multiplicando-se em outras vozes). De qualquer modo, é este jogo polifónico entre a voz do locutor ser do mundo e a voz do locutor da enunciação que funciona como uma das estratégias de construção da imagem pessoal por parte do locutor empírico.

Por isso, a manipulação que o locutor faz da deixis pessoal é determinante, tornando-o no principal responsável pela construção não só da sua imagem pessoal, como também da imagem do alocutário, como confirma Marques (2000: 174): “A imagem do locutor e do(s) alocutário(s) emerge, em larga medida, do uso consistente que o locutor faz dos pronomes e de outros dispositivos linguísticos de referência pessoal."

\subsubsection{O Quadro da Alocução}

Partindo da proposta de Goffman (1981), Kerbrat-Orecchioni (1999: 26-29) apresenta um esquema sobre o estatuto participativo do receptor ${ }^{16}$ na interacção verbal. Interessar-nos-á destacar os aspectos desse formato da recepção que são pertinentes para a caracterização do debate televisivo e que, de resto, foram tidos em consideração na análise sobre o "Duel sur la Cinq", realizado por Doury (1995). Segue-se assim o esquema proposto por Kerbrat-Orecchioni na Figura 2, em baixo:

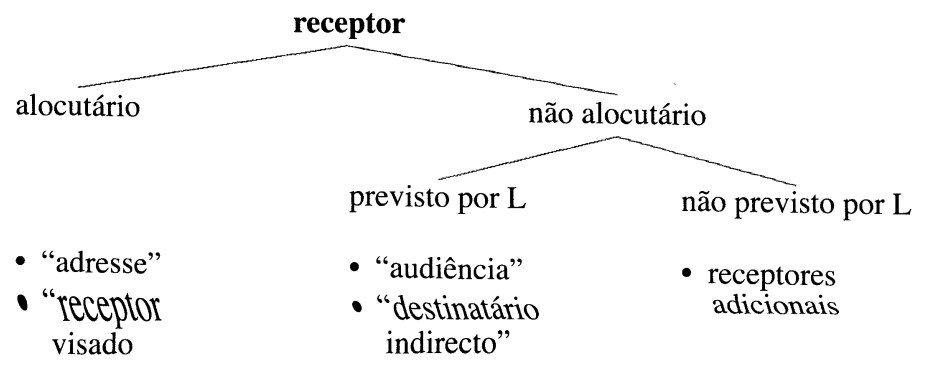

Figura 2: O quadro da alocução proposto por Kerbrat-Orecchioni (1999)

\footnotetext{
${ }^{16} \mathrm{O}$ esquema do estatuto participativo do receptor apresentado por Kerbrat-Orecchioni em 1999 é uma reelaboração depurada do mesmo esquema baseado na proposta de Goffman (1981) que Orecchioni desenvolveu em 1990, em Les Interacctions Verbales (Tomo I: 86-99). Apesar de termos tido os dois esquemas em consideração, focalizámo-nos no mais recente, por nos parecer ter simplificado a questão do destinatário indirecto, que no primeiro esquema flutuava entre os "ratified participants" e os "bystanders" e que no esquema de 1999 se fixa dentro dos "bystanders" ou "não-alocutários".
} 
Orecchioni considera assim dois tipos de receptores:

- o alocutário propriamente dito, que se define pelo facto de ser explicitamente considerado pelo emissor L (através do uso da deixis pessoal da segunda pessoa e/ou pela direcção do olhar) como parceiro na relação de alocução e que é parcialmente determinado pela imagem que o locutor constrói de si mesmo; é também o destinatário directo, e pode ser singular ou plural, nominal ou anónimo, real ou fictivo. No caso concreto do debate televisivo, estes destinatários são frequentemente plurais, nominais e reais, sendo constituídos pelos intervenientes no debate e pelo moderador.

- o não-alocutário, que pode ser:

- previsto pelo locutor, constituindo-se um destinatário indirecto, normalmente presente fisicamente na situação comunicativa do debate televisivo e podendo inclusive ter possibilidade de resposta (em debates onde por exemplo possa haver participações do público presente ou dos telespectadores sob a forma de chamada telefónica para o programa). Dentro do quadro participativo do debate televisivo, este tipo de receptor é identificado com a audiência presente e com os telespectadores em casa, na medida em que ambos os tipos de público são previstos pelos locutores. Mas pode também existir um destinatário indirecto dentro do grupo dos alocutários oficialmente instituídos, em debates com um quadro participativo mais complexo. Nestes casos, a sua referência no discurso dos locutores pode ser feita através do que KerbratOrecchioni (1990: 92) designa por tropo comunicacional, ou seja, um artifício enunciativo através do qual o destinatário directamente convocado pelos indícios de alocução é afinal um destinatário secundário, sendo afinal o destinatário indirecto o alvo privilegiado.

- não previsto pelo locutor, constituindo receptores adicionais, espécie de "intrusos indiscretos, de espiões ilegais" (Kerbrat-Orecchioni 1990: 86), como as pessoas que escutam por casualidade uma conversa através da porta e que interceptam uma mensagem do locutor que não lhes é destinada. No caso do debate televisivo, este receptor pode ser, por exemplo, o analista do discurso ou um telespectador estrangeiro que, por engano, sintonize a estação televisiva portuguesa que difunde um debate sobre a situação política, económica e social do país (como é o caso do debate que serve de corpus a este trabalho).

Kerbrat-Orecchioni (1990: 90) defende que, sendo a configuração do formato da recepção muitas vezes instável, se deve falar em hierarquia de destinatários, em lugar de tentar decidir rigidamente sobre o estatuto directo ou indirecto de um alocutário: 
Cette «instabilité structurale» (Goffman 1981: 35) concerne aussi bien: [...] qu'à l'intérieur de la catégorie des participants, la distinction entre destinataires directs et indirects : la description doit souvent renoncer à cette dichotomie, et lui préférer l'idée d'une hiérarchie de destinataires [...], c'est-à-dire que, sans être pour autant «unaddressed», un destinataire peut l'être de façon secondaire, par rapport au(x) destinataire(s) privilégié(s) a qui s'adresse surtout le parleur [itálicos nossos].

No debate televisivo, Doury mostra que cada "débateur" estabelece uma rede de destinatários organizados hierarquicamente e a quem se dirige num jogo de implícitos/explícitos, directa e indirectamente. Doury (1995: 229) identifica três tipos de alocutários (ou destinatários ${ }^{17}$ na sua expressão):

1) o seu adversário "qui constitue son alter ego" na medida em que possui o mesmo direito à palavra que ele próprio e a quem se dirige directamente;

2) o "animador" ou moderador, colocado no mesmo plano que o público que está no estúdio, embora nós consideremos este público no mesmo plano que os telespectadores;

3) o conjunto de telespectadores que Doury considera como "véritables destinataires de l'argumentation".

O sistema de convocatória dos diferentes destinatários faz-se através de operadores linguísticos bem conhecidos (sendo o principal a marca de segunda pessoa), embora muitas vezes se crie o designado "tropo comunicacional", como já foi referido. Doury (1995: 230) observa também que a instauração e hierarquização dos alocutários/destinatários pode decorrer de uma análise do direccionamento dos olhares do locutor, o que por si só poderá bastar para convocar um alocutário.

${ }^{17}$ Doury parece utilizar receptor como sinónimo de destinatário. Entendemos aqui o conceito de receptor como entidade nascida na teoria da informação e que era a pessoa que recebia e descodificava a mensagem. Apesar de ter sido substituído pela designação de "destinatário" no esquema proposto por Jakobson (1960), o receptor era percebido como entidade exterior ao processo da enunciação. KerbratOrecchioni (1999: 26) propôs, sob a designação geral de receptor, a distinção de três tipos de alocutários (directos, indirectos e adicionais - não previstos) e não distingue alocutário de destinatário. Neste enquadramento teórico, o destinatário é o sujeito empírico simétrico ao emissor.

Entendemos aqui o conceito de destinatário no enquadramento da Teoria Polifónica de Ducrot (1980, 1982, 1984), que o coloca num segundo nível da polifonia, como entidade simétrica ao enunciador, entidades "donées comme responsables de tel ou tel acte de langage"(Ducrot 1982: 76), a quem o locutor imagina que se dirige. Ducrot (1980: 39) mostra que no enunciado "A ordem será mantida custe o que custar" proferido pelo Ministro do Interior (=Locutor) se dirige a um alocutário colectivo constituído pelos cidadãos franceses, prevendo também dois destinatários: os bons cidadãos, a quem faz a promessa e os maus cidadãos, a quem dirige a ameaça. 
Contudo, a autora lembra que, apesar do que afirma, o olhar desempenha também outras funções numa interacção e que pode não constituir um critério unívoco de identificação do destinatário principal (Doury 1995: 231). Na verdade, o desejável seria que o analista do discurso dispusesse do conjunto total de indicadores verbais e não verbais (orientação do corpo, direcção do olhar, modulação prosódica da voz) para a determinação mais precisa da hierarquia de receptores, uma vez que a informação verbal por si só é sempre parcelar em relação ao que efectivamente se passa em alguns tipos de discurso, como por exemplo num debate mediatizado. No entanto, as dimensões não verbais do debate não serão consideradas no nosso estudo neste momento, na certeza de que é um aspecto que deve ser considerado em futuros desenvolvimentos deste tema.

Para a caracterização do receptor, importa ainda considerar a relação sócio-afectiva que este estabelece com o locutor, traduzida em termos de grau de aproximação vs distância, uma vez que esta informa acerca da hierarquia social e das relações de coligação ou oposição estabelecidas entre os participantes no debate:

\begin{abstract}
Dans la définition du récepteur, il convient enfin de faire intervenir la relation socio-affective qu'il entretient avec le locuteur. Cette relation se définit elle-même à partir de différents paramètres (degré d'intimité qui existe entre les deux partenaires de l'échange verbal, nature des rapports hiérarchiques qui éventuellement les séparent, et du contrat social qui les lie) mais elle se ramènerait, selon Perret (1968), à un archi-axe graduel distance/non distance qui subsumerait à la fois l'axe de l'intimité et de la domination social (et qui intervient par exemple, de façon déterminante dans l'utilisation des pronoms «vous» vs «tu») (Kerbrat-Orecchioni 1999: 29) [itálicos nossos]
\end{abstract}

Neste caso, e como observa Marques (2000: 179), deve ser também considerada a "dimensão sociolinguística do uso dos pronomes pessoais [...], assinalando o estatuto social dos interlocutores", como elemento definidor das relações interpessoais que se estabelecem com o alocutário.

Finalmente, a selecção dos participantes num debate deve ser democrática: "A composição do painel é importante porque deve dar a imagem de um equilíbrio democrático..." (Bourdieu 1997: 32) Este condicionamento é ainda mais importante quando se está perante o debate político num estado democrático, em que as principais facções ideológicas devem estar representadas, sob pena da estação de televisão que acolhe o debate poder transmitir à opinião pública uma imagem de falta de isenção política. Trata-se, porém de uma situação que nem sempre acontece, como observa Bourdieu (1997: 32), na medida em que o painel é constituído pelas pessoas que aceitaram vir ao programa, o que nem sempre corresponde à representação mais equilibrada das tendências políticas ou ideológicas: 
há pessoas que não se pensa sequer em convidar e pessoas que são convidadas e que recusam. Eis o painel, e o que é percebido esconde o não percebido: não vemos, num percebido que é construído, as condições sociais de construção.

\subsubsection{O público}

O público é, possivelmente, uma instância menos importante dentro do quadro da alocução (na medida em que é um não alocutário), mas é talvez a mais importante dimensão dentro do quadro participativo, porque é para ele que se orienta a argumentação dos "débateurs". O papel central do público na construção da argumentação é também defendido por Breton (1998: 28):

Argumentar é (...) agir sobre a opinião de um auditório, de tal maneira que se abra um espaço, um lugar para a opinião que o orador lhe propõe (...) é construir uma intersecção entre os universos mentais em que cada indivíduo vive [itálicos nossos].

O público, apesar de se ver reduzido à condição de espectador, representa, assim, o destinatário último e principal, exigindo pela parte dos "débateurs" uma especulação a respeito da sua configuração em termos de estatuto socio-económico, pressupostos ideológicos, experiências adquiridas e partilhadas e referências culturais. Trata-se, por isso, de uma coordenada fundamental a ter em conta pelos participantes no debate, condicionando as suas estratégias de argumentação e a construção do seu ethos.

O público do debate televisivo, quer seja a audiência que partilha o mesmo espaço físico que os participantes e o moderador, quer seja a massa abstracta de telespectadores que assiste ao programa em casa, ou ambos, deve ser considerado enquanto "entidade colectiva mas funcionalmente heterogénea", nas palavras de Marques (2000: 169). "Entidade colectiva" e abstracta, na medida em que representa a "Opinião Pública" em geral e se identifica com a figura indiferenciada do "Povo" (Marques 2000: 170). "Funcionalmente heterogénea" na medida em os vários locutores do debate vão dirigindo sequências da sua argumentação para diferentes destinatários, consoante o assunto em discussão e a estratégia argumentativa.

\section{Prós e Contras: um debate político televisivo}

O corpus que serviu de base ao presente trabalho é constituído pela totalidade do programa Prós e Contras, emitido a 6 de Janeiro de 2003 pela cadeia de televisão pública RTP1. Este material audio-visual foi gravado em formato VHS e posteriormente convertido para suporte digital, através da gravação e conversão do formato original numa extensão adequada a ficheiros de som (.wav). Por razões de delimi- 
tação do objecto de análise à dimensão linguística da interacção verbal do debate televisivo, vimo-nos, neste trabalho, obrigados a não estudar a dimensão visual do programa (sobretudo ao nível das dimensões cinésica e proxémica), estando, apesar disso, conscientes da sua importância para a compreensão global de qualquer tipo de interacção verbal. Em trabalhos futuros, essa dimensão deverá, contudo, ser também tida em consideração. Posteriormente, o corpus, constituído por cerca de três horas de gravação, foi manualmente etiquetado à palavra, tendo ainda em consideração aspectos de vocalização fonética e modulação prosódica (sobretudo ao nível da duração das pausas, dos contornos entoacionais e de sinais paralinguísticos, como expiração, riso, tosse, etc). Para a análise de Prós e Contras, e após termos comparado vários modelos de transcrição de corpora orais, optámos pela proposta de Rodrigues (1998) com poucas alterações (de notar a localização temporal do excerto no ficheiro wave e algumas informações para-textuais), que adaptou para o português o sistema de transcrição de Kallmeyer/Schütze (1976).

A análise deste debate tem em conta o tipo de discurso, o seu quadro comunicativo e participativo, na linha da proposta de Kerbrat-Orecchioni, a que acrescentamos uma análise das suas dimensões política e polémica e o formato ritualizado a que obedece.

\subsection{O quadro comunicativo do programa televisivo Prós e Contras}

No âmbito do quadro comunicativo da sessão do debate Prós e Contras que nos serve de corpus de estudo, analisaremos o quadro espacio-temporal, as suas dimensões política e polémica, o seu formato e ritualização, os seus objectivos comunicativos e o seu quadro participativo.

\subsubsection{O quadro espacio-temporal ${ }^{18}$ de Prós e Contras}

O debate televisivo Prós e Contras é um programa transmitido em directo pela RTP1, uma vez por semana (às segundas-feiras) ${ }^{19}$, por volta das 22:30, com uma

${ }^{18}$ Kerbrat-Orecchioni (1990: 77-78) considera como componentes do enquadramento espacial: 1) os seus aspectos puramente físicos, "quelles sont les caractéristiques du lieu où se déroule l'intéraction (...); est-ce un lieu ouvert ou fermé, public ou privé, vaste ou resserré; comment se présentent le "décor", et l'organisation proxémique de l'espace (...)"; 2) os seus alcances social e institucional: "la vie sociale a pour théatre un certain nombre de «settings», cadres sociaux définis qui ont une certaine finalité, et où les comportements sont régis par un ensemble de proscriptions conventionelles connues de tous les membres compétents de la communauté (...)". Kerbrat-Orecchioni destaca ainda o papel determinante do enquadramento temporal para o desenrolar da interacção, traduzido em aspectos como: "à quel moment de la rencontre convient-il exactement de saluer ? à partir de quand et jusqu'à quand est-il convenable d'offrir ses voeux de nouvel an?"

19 Mais tarde o programa passou a ser transmitido às terças-feiras. À data de redacção deste trabalho o programa ainda está no ar. 
duração média de uma hora e meia. A sessão que serviu de base a este trabalho durou, porém, cerca de 3 horas.

No plano do seu enquadramento espacial, o debate Prós e Contras é transmitido a partir de Lisboa. A RTP 1 não tem estúdios apenas em Lisboa, mas entendemos que o facto deste debate ser transmitido a partir de Lisboa não terá grande significado, a não ser o facto de ser em Lisboa a sede da estação de televisão. Por outro lado, sendo Lisboa a capital política e administrativa do país, local onde está instalado o governo e a oposição, é mais natural que o debate seja transmitido a partir desta cidade, por ser mais acessível aos convidados políticos.

O facto de o programa decorrer dentro de um estúdio atribui poder de iniciativa à instância mediática, na opinião de Charaudeau/Ghiglione (2000: 63):

A escolha do local, do enquadramento do debate, tem incidências sobre o tipo de legitimidade que o media se quer atribuir.(...) O estúdio: são sempre dados ao espectador indícios de identificação deste lugar. Este lugar, sendo reconhecido como tal, sugere que é a instância mediática que tem a iniciativa deste encontro entre pessoas que foram convocadas para vir debater. Isto visa um efeito de «auto-celebração» desta instância, indicando que ela tem o perfeito controlo de uma cerimónia (...) [itálicos nossos].

Esse poder da instância mediática, representado pela figura do moderador, é traduzido no poder de selecção dos convidados e reflectido no poder de condução de todas as partes do debate e de atribuição e gestão da palavra. A emissão decorre dentro de um estúdio com um formato de salão-teatro, dividido em duas partes:

- a cena, ou palco, onde são colocados os participantes dispostos por dois painéis, Pró e Contra, e onde circula de pé a moderadora; os painéis estão dispostos diametralmente, dividindo o local em duas zonas idênticas e colocando os participantes numa relação de frontalidade, de face a face, e que como observam Charaudeau e Ghiglione, é frequente em debates políticos, sugerindo que "vai haver uma confrontação, o que produz um efeito de «espectacularização» polémica"(Charaudeau/Ghiglione 2000: 63)

- a plateia, onde está sentado o público, sendo a primeira fila reservada para os convidados do público seleccionados pelo programa e que representam a sociedade civil portuguesa; também na primeira fila estão sentados os três convidados directores de jornais que terão, como veremos, uma função especializada, diferente da função de testemunho e de exemplaridade atribuída aos restantes convidados do público. 


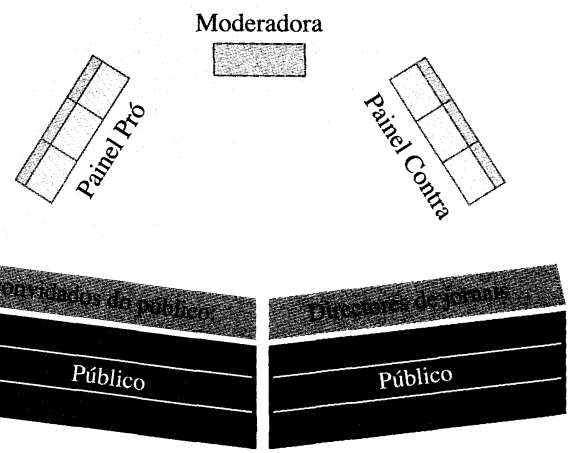

Figura 3: Esquema da disposição espacial dos participantes no estúdio em Prós e Contras.

A disposição espacial dos participantes no estúdio em Prós e Contras pode ser ilustrada pela Figura 3 e observada nas imagens da Figura 4.

Esta disposição espacial parece enquadrar-se dentro de uma aposta topológica representativa do aparelho democrático baseado numa "interacção consensual", como defendem Charaudeau / Ghiglione (2000: 160): “O «salão-teatro» (...) como lugar emblemático onde se exibe uma democracia fundada na interacção consensual entre os homens e a acumulação da sua diversidade".
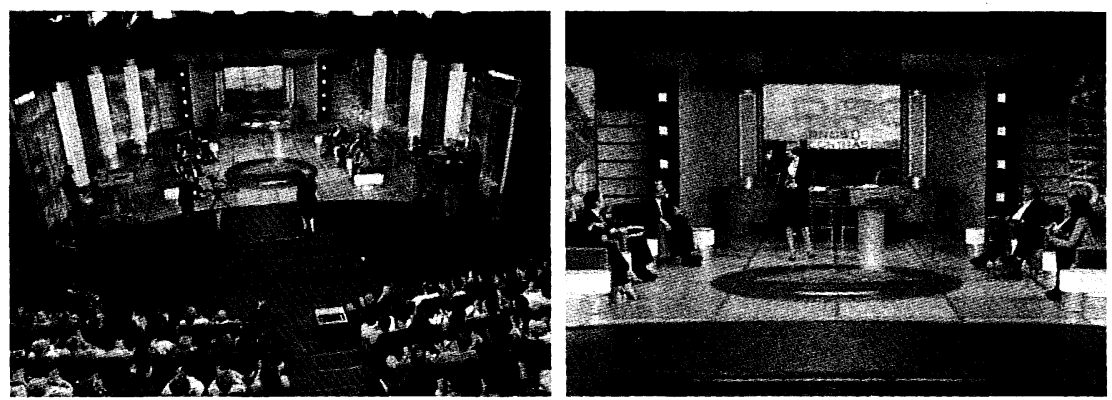

Figura 4: Imagens do estúdio onde se realiza o debate Prós e Contras.

A disposição espacial, visando o efeito de fórum, parece assim configurar os ideais do funcionamento da democracia directa, determinando a selecção dos participantes e a atribuição dos seus papéis, como ilustra a Figura 5.

No que respeita à sua localização temporal, o debate Prós e Contras que serviu de corpus a este trabalho realizou-se no dia 6 de Janeiro de 2003, constituindo o primeiro debate televisivo do ano de 2003 dentro da sua série e um dos mais repre- 
sentativos dessa semana no quadro de todas as cadeias de televisão portuguesas. A questão oportunamente trazida a debate: "2003 vai ser um ano bom ou mau para Portugal?", enquadrava-se perfeitamente no momento de reflexão habitual em cada transição de ano civil, adivinhando prognósticos políticos e económicos para Portugal no decurso do ano que começava.

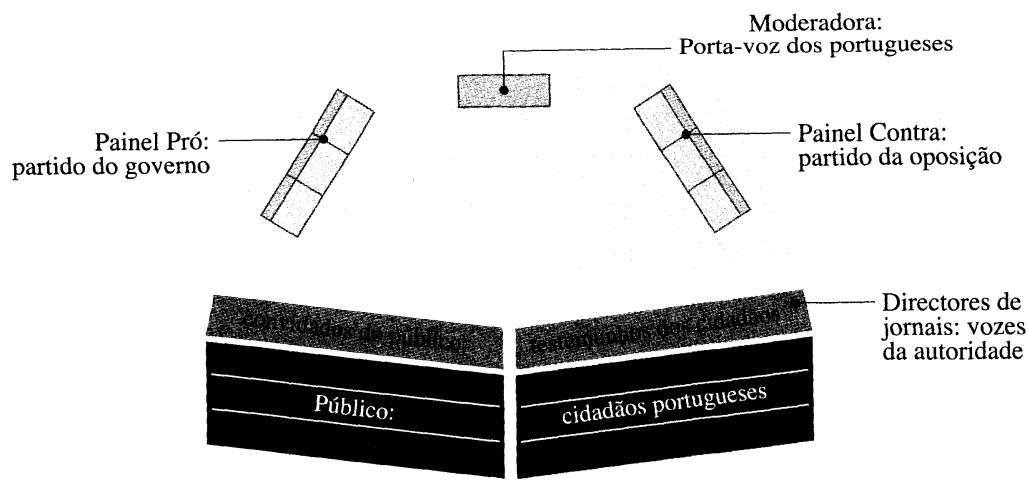

Figura 5: Esquema da disposição espacial dos participantes e seus papéis em Prós e Contras.

O momento político era dominado por um governo de coligação PSD/CDS-PP, sob a liderança do primeiro-ministro Durão Barroso, eleito em Março de 2002 e por uma situação económica do país globalmente em pior estado, após um ano de governação. Este debate surge assim como um momento em que a nação, pela voz da moderadora Fátima Campos Ferreira, exige esclarecimentos e respostas por parte do governo, no início de mais um ano de governação social-democrata. Esta conjuntura será assim determinante na selecção quer dos convidados, quer dos dois painéis de participantes e que viriam a ser, como é óbvio, de um lado os representantes do governo em exercício, e do outro lado, os representantes da oposição, como veremos mais à frente.

$\mathrm{O}$ enquadramento conjuntural do país foi apresentado numa peça em formato audio-visual, transmitida no início do programa, e que tem como função legitimar a voz da moderadora, porta-voz da nação, ou seja, conferir-lhe os argumentos de autoridade de que irá servir-se durante a condução do debate. Os aspectos fundamentais da conjuntura político-económica e social do país, apresentados na peça audio-visual, poderão resumir-se aos seguintes tópicos:

- aumento do custo de vida para 2003 (renda da casa, luz, água, portagens);

- sondagem feita pelo DN e pela TSF revela pessimismo dos portugueses; 
- escândalos em 2002 provocaram uma crise de confiança (caso Moderna, corrupção na GNR e no futebol, pedofilia na Casa Pia);

- portugueses mantêm os salários mais baixos da Europa, o pior nível de vida, a maior taxa de iliteracia e a mais baixa taxa de produtividade da União Europeia;

- há ausência de reformas estruturais que foram agravadas por 6 anos de governo socialista;

- o novo governo exige que se cumpra os $2,8 \%$ de défice, o que cria muitas dificuldades económicas ao país;

- em 2004, a EU prepara-se para integrar 10 novos países de Leste com economias mais competitivas;

- Durão Barroso continua optimista e diz que em 2006 teremos o maior crescimento económico da EU.

\subsubsection{As dimensões política e polémica de Prós e Contras}

As temáticas que são trazidas para este debate colocam-no inevitavelmente na esfera do discurso político, além do estatuto dos participantes no debate, no que diz respeito à sua função social de representantes de um partido político. São já inúmeras as propostas de definição de discurso político ${ }^{20}$ em Análise do Discurso. Consideraremos para este trabalho a definição que Marques (2000: 30) faz de discurso político, a partir da proposta de Bronckart (1985), na medida em que estabelece a relação entre discurso político, debate político e discurso polémico:

No que aqui nos importa, o discurso político é

[le] texte d'un acteur politique défini qui intervient dans un débat publique pour convaincre et/ou faire agir les destinataires du texte. Du point de vue de l'ancrage, on peut supposer que le texte politique créé la fiction d'un rapport direct avec l'interlocuteur et est situé par rapport au moment de production. Pour convaincre, l'énonciateur devra toutefois aussi adopter un point de vue général (...) et par conséquent s'abstraire de la situation immédiate de production (Bronckart 1985: 115)

Se, por um lado, [esta definição] reduz o conceito de discurso político ao de debate político, ou seja, um discurso de base polémica e, ao mesmo tempo, exclui outras categorias tradicionalmente consideradas discurso político, por outro lado, e estas são características que marcam a especificidade deste discurso, a particularidade de abertamente visar a persuasão obriga à presença explícita do alocutário no discurso (...) (Marques 2000: 30)

\footnotetext{
${ }^{20}$ Para um percurso sobre as várias propostas de definição do discurso político em Análise do Discurso, veja-se Pires (2002: 5-9).
} 
Marques (2000: 30) põe a tónica na função social adoptada pelo locutor no momento da enunciação de um discurso público:

São "discurso político" todas as actividades de comunicação verbal públicas dos elementos que integram as diferentes instâncias governativas, enquanto representantes desses mesmos organismos. Exemplificando, $o$ «ministro $X$ » produz um discurso político quando fala em nome do seu ministério, governo, partido, mas não enquanto "adepto $X$ » do «clube de futebol $Z$ » [itálicos nossos].

Em Prós e Contras encontramos assim 'discurso político' sempre que os participantes no debate discutem medidas económicas, reformas educativas, assuntos da política nacional, enquanto representantes dos seus partidos. Vemos assim, por exemplo, Rui Rio, do partido do governo, a responsabilizar o partido socialista, que governou anteriormente, pelo endividamento económico e pelas dificuldades sociais que o país atravessa:

RR: $[. . .$.$] agora (.).(-)$ a questão que está aqui $\left.(..)()^{\circ}\right)$ e esta é que foi a irres-
ponsabilidade do partido socialista, é que fez esse défice, gastou acima
das suas possibilidades num momento em que deveria ter equilibrado
orçamento. E por isso nós agora estamos a pagar precisamente esses erros
que se $X X X[F R]$ deixe-me só terminar para dizer isto $[. . .].\{T 8,00: 52-1: 10\}$

Existem, porém, outros momentos no programa em que não há discurso político, em sentido estrito, quando os locutores são os convidados do público entrevistados pela moderadora, que falam como 'exemplares' da sociedade civil, como veremos adiante na caracterização do quadro participativo. Este é mais um exemplo de heterogeneidade composicional dos enunciados, inerente a qualquer tipo de texto/discurso, e que é também verificável em Prós e Contras.

A natureza do discurso político conduz muitas vezes à polémica, devido aos naturais dissensos entre ideologias partidárias. $\mathrm{O}$ carácter polémico ${ }^{21}$ deste discurso intensifica-se quando o discurso político surge associado ao debate, cuja natureza implica desde logo confronto de opiniões antagónicas:

Le débat est une discussion plus organisée (...): il s'agit encore d'une confrontation d'opinions a propos d'un objet particulier (Note: qui implique donc un minimum de désaccord entre participants) (Kerbrat-Orecchioni 1990: 118).

${ }^{21}$ Para Kerbrat-Orecchioni (1999: 175) o discurso polémico implica três actantes abstractos, a saber: “(...) un locuteur polémiste, qui vise à desacréditer; une cible aux yeux d'un; destinataire, que L cherche à se constituer comme complice." 
Ainda segundo Charaudeau/Ghiglione (2000: 69-70), o "discurso de controvérsia", que entendemos como polémico, próprio do mundo político, pode ser objecto de dois tipos de encenação televisiva:

- a primeira, que consiste em colocar dois políticos frente a frente com ideias antagónicas e em que cada um tenta derrubar o outro verbalmente;

- a segunda, que consiste em confrontar vários pontos de vista sobre o mesmo assunto não necessariamente contrários.

O caso de Prós e Contras enquadra-se no segundo tipo de encenação, naquilo que os autores designam por uma ágora (debate disciplinado) ${ }^{22}$, em que cada um intervém com a sua opinião, e estabelece com os outros participantes relações de coligação ou de oposição.

Embora assentando no mesmo princípio de confronto de ideias defendido por Orecchioni, a definição de discurso polémico segundo Amossy (2000: 209) é mais radical e agónica, na medida em que o objectivo do locutor se resume a destruir a argumentação do alocutário, que é visto como um inimigo a abater:

Il [le discours polémique] s'agit d'une confrontation d'opinions mettant l'accent sur la divergence des points de vue en refusant et en attaquant les arguments de l'autre, sans se soucier de les considérer sérieusement. La polémique repousse les compromis - elle s'oppose en cela à la négociation - et considère que la position adverse est un ennemi a abattre (...). Agonale, elle fait usage d'une violence plus ou moins affichée et tend a glisser vers la délégitimation de l'opposant en usant aussi bien d'arguments ad hominem, qu'ad rem. Elle dresse ainsi un Proposant sourd aux raisons de l'autre, contre un Opposant qui est considéré comme un ennemi à vaincre plutôt qu'à convaincre (...)[itálicos nossos].

Herrero (2001: 1584-1585), na linha de Kerbrat-Orecchioni, caracteriza também o discurso polémico ao nível da conversação, enumerando as seguintes propriedades:

- "es de naturaleza verbal (oral)", na medida em que se refere à polémica ao nível de um tipo de interacção verbal em que se insere a conversação;

- “es de tipo dialógico", na medida em que existem pelo menos dois interlocutores que apresentam posições antagónicas ou contrárias; o dissenso é condição para haver polémica;

${ }^{22}$ Os autores atribuem a designação de fórum a uma organização não disciplinada, por oposição à ágora que é uma organização disciplinada (Charaudeau/Ghiglione 2000: 70). 
- "se desarrolla cara a cara", uma vez que os interlocutores devem estar presentes no mesmo espaço, embora o autor reconheça que pode haver situações em que um dos interlocutores não está presente mas cujo discurso é difundido por telefone ou por satélite;

- "contiene como rasgo inherente el desacuerdo o la disensión entre dos manifestaciones que se confrontan, o dos polemizadores que se enfrentan" (itálicos do autor), ou seja, o discurso polémico radica numa expectativa de desacordo, de dissenso;

- "presenta un blanco, un objetivo sobre el que recae el desacuerdo"; o autor considera que podem ser alvos do ataque o interlocutor, o conteúdo do seu discurso ou a forma e intencionalidade do mesmo.

Em Prós e Contras, a dimensão mais radical de discurso polémico apresentada por R. Amossy é mais vezes usada pelo painel Contra, designadamente por Fernando Rosas, que chega mesmo a usar argumentos ad personam ${ }^{23}$ contra a Ministra das Finanças em exercício, Manuela Ferreira Leite:

$\mathrm{FR}^{24}$ : deixe-me dizer (..)(.) no discurso cultural (..)(') que é uma espécie de novo discurso neo-decadentista (..)(.) que portugal vem por aí abaixo(,)(') há uma decadência $(),\left({ }^{\circ}\right)$ finalmente $(),(-)$ apareceu um governo que (..)(') uma espécie de (,) neo-bonapartismo que nos vai endireitar com (-)(..) por obra de uma espécie de (,)(-) por uma espécie de salazar de saias adaptado ao século vinte que é a (..) (-) que é a ministra das finanças (..)(.) eh este discurso $(),(-)$ este discurso

FCF: salazar de saias adaptado ao século vinte e um (?) [risos público]

FR: uh eh exactamente (..)(.) eh exactamente (..)(,) [risos público]

FCF: está a referir-se à doutora manuela ferreira leite (?)[risos público]

FR: a receita a receita a receita financeira (..)(-) a receita financeira da doutora manuela ferreira leite (,) d'um ponto de vista teórico (..)(')é muito semelhante à receita do salazar em mil novecentos e vinte e oito $(!)\left({ }^{\circ}\right)(.).[\ldots .].\{\mathrm{T} 25$, $00: 57-1: 37\}$

${ }^{23}$ Plantin (1996: 86-87) inscreve este tipo de argumentos no âmbito do ataque pessoal e distingue a "refutação ad hominem" (argumentação que visa desacreditar e descredibilizar o discurso do outro), da "argumentação ad personam", i.e., o ataque pessoal, o insulto. Plantin acrescenta que, apesar de a deontologia da interacção e as regras de delicadeza não permitirem o insulto ao adversário, a ironia sobre o adversário pode provocá-lo a ponto de o seu comportamento consequente prejudicar a sua imagem. Neste caso, o destinatário do "insulto", Manuela Ferreira Leite, não é alocutário de Fernando Rosas, o que não impediu as várias reacções, por parte da moderadora e do público, e a manifestação de censura de Pacheco Pereira.

${ }^{24}$ Confrontar Anexo para as siglas dos participantes do corpus que constitui o debate. 
Numa perspectiva mais ou menos radical, o discurso polémico visa sempre uma desacreditação do alocutário, estratégia que é seguida desta vez por Medina Carreira, do painel Pró, quando invoca a sua autoridade, antiguidade e logo superioridade em relação aos "débateurs" do painel Contra, no que diz respeito à matéria económica da justiça fiscal:

FCF: mas(,)(') 6 ó professor medina carreira (,) a reforma fiscal (,)() por um lado(,)(') e a reforma do sistema(,)(') a: não são por exemplo uma pedra de toque um.ito importante e basilar para dois mil e três(?)

$\mathrm{MC}$ : ó fátima quando nenhum destes senhores falava de justiça social (,)(') já eu falava (..)(') e já apresentava soluções

FR: [XXXXX eu também já tenho uma certa idade]

MC: ai já já já (,) ) já já já já já

$\mathrm{RC}$ : [XXXX há que reconhecer a preocupação com a justiça fiscal mas (,) mas enfim (')(..) XXXX

MC: já eu não me lembro de nenhum dos presentes falar disso quando eu falava (.)(') bom (,)(.) portanto eu não venho aprender a prioridade da justiça fiscal aqui (!)(“)(..) [riso de RC] nem aqui nem ali (!)(")(..) em parte nenhuma $(),($.$) agora (),($.$) é preciso ter a noção da sociedade que somos (),\left({ }^{\circ}\right)$ da máquina administrativa que temos $(),\left({ }^{\circ}\right)$ e dos maus hábitos que estão instalados na vida portuguesa (.)(..)[....]\{T30, 3: 49-4:29\}

\subsubsection{Prós e Contras - formato e ritualização}

O programa televisivo Prós e Contras obedece a um formato pré-estabelecido e ritualizado que é comum a outras emissões da mesma série e que pode ser resumido na seguinte tabela:

1. saudação e anúncio da questão em debate

2. anúncio dos convidados presentes no debate

3. anúncio de uma mini-reportagem audiovisual

4. anúncio da sondagem televisiva

$1^{\text {a }}$ Parte

5. debate

6. entrevistas (IK, JMP)

7. retoma do debate

8. anúncio do resultado provisório da sondagem

9. anúncio do intervalo

Intervalo 


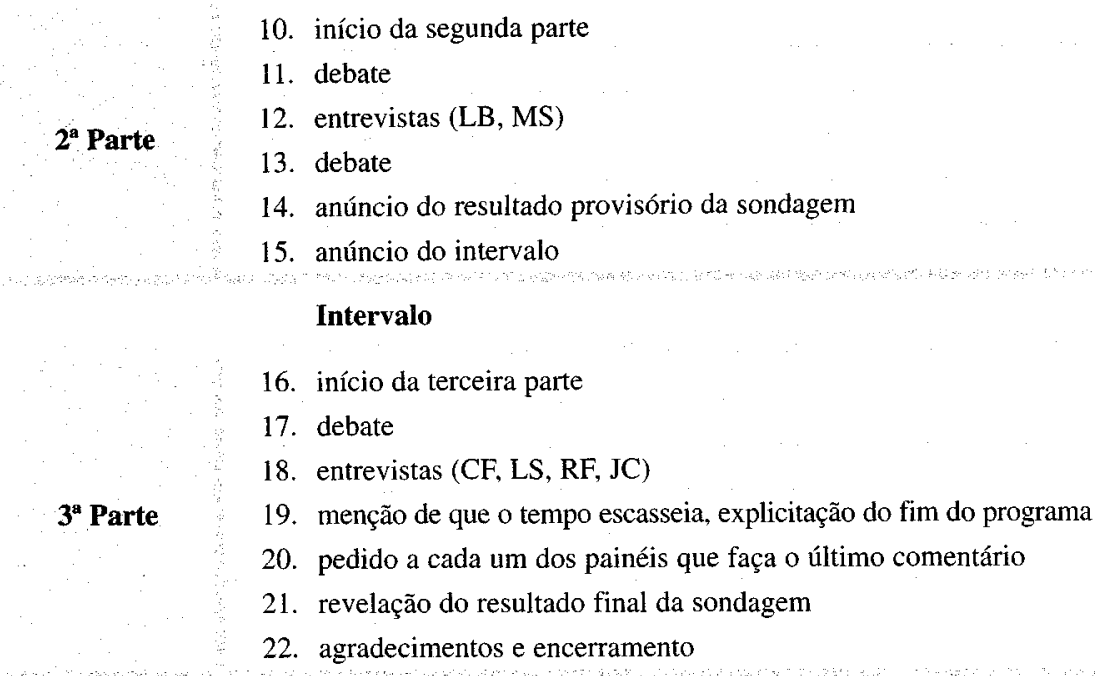

Tabela 1: Esquema da estrutura do programa Prós e Contras.

Do ponto de vista discursivo, o programa Prós e Contras é, à semelhança da quase totalidade dos discursos do nosso quotidiano, um espaço de heterogeneidade composicional de enunciados, de onde se destaca o género debate que serve de objecto de estudo deste trabalho, embora outros tipos de discurso irrompam ao serviço do debate, como a entrevista, a peça audiovisual que funciona como documentário na primeira parte do programa ou as mensagens escritas enviadas pelos telespectadores que circulam em rodapé no ecrã de televisão ${ }^{25}$.

Ainda do ponto de vista estrutural, há que reiterar a já mencionada centralidade da moderadora como condutora e reguladora do debate, a quem cabem as funções de balizar a abertura e o encerramento do programa, de gerir as tomadas de vez dos participantes no debate e os conteúdos que pretende ver debatidos e de assegurar que as atribuições da palavra são temporal e democraticamente equilibradas para cada um dos dois painéis intervenientes.

\footnotetext{
25 As mensagens escritas enviadas por telemóvel e difundidas no rodapé do ecrã de televisão funcionam como mais um espaço de intervenção dos telespectadores no programa, para além da sondagem de opinião lançada no início do programa. A natureza muito específica e ainda pouco estudada deste tipo de discursos não será aqui analisada por se afastar dos objectivos deste trabalho, embora constitua uma amostra muito interessante do impacto que o debate está a ter em tempo real no telespectador. Este espaço discursivo representa mais um alargamento democrático do fórum em que decorre o debate à sociedade civil.
} 
Obedece ao formato ritualizado do programa a composição do quadro de participantes: os dois painéis Pró e Contra, com três participantes em cada lado, e os convidados do público, que se sentam na primeira fila da plateia e que servem de motivação para lançar novas questões para o debate.

Nesta sessão do programa Prós e Contras, a moderadora convida três participantes especiais, cujo estatuto será analisado no ponto seguinte, que não costumam fazer parte do quadro participativo deste programa: os directores de jornais. Foge também à regra do formato do programa a duração desta sessão, que se aproxima normalmente de uma hora e meia e que nesta emissão rondou as três horas. A dimensão televisiva da emissão em directo coaduna-se também com o formato do programa, marcado pela espontaneidade e pelo improviso das intervenções, a par da sondagem dos telespectadores que serve de pano de fundo ao debate.

\subsubsection{O objectivo comunicativo de Prós e Contras}

Kerbrat-Orecchioni (1990: 79) entende que "o objectivo da interacção verbal se localiza entre o quadro espacio-temporal, que possui muitas vezes uma finalidade própria, e os participantes, que possuem os seus objectivos individuais". A autora baseia-se novamente em Brown/Fraser (1979) para apresentar uma tipologia de três níveis de objectivos subjacentes à interacção verbal:

le «maxi-purpose», ou but global de l'interaction (ex.: «visite chez le médecin»), et les «mini-purposes», buts plus ponctuels qui correspondent à chaque acte de langage particulier réalisé au cours du déroulement de l'interaction ; ainsi qu'un niveau intermédiaire, celui des «tasks» (qui correspond en gros à l'unité qu'on appellera plus loin «séquence») (Kerbrat-Orecchioni 1990: 79) [itálicos nossos].

Na descrição do debate Prós e Contras, faremos apenas referência aos objectivos globais ou "maxi-purposes" deste tipo de interacção, na medida em que pretendemos associar este aspecto do quadro comunicativo à caracterização do debate como um género. Da mesma forma, teremos apenas em consideração os objectivos préexistentes ou "exteriores" à concepção do debate Prós e Contras, e não os objectivos internos que vão sendo construídos ao longo do debate ou negociados pelos participantes.

Da análise da configuração do espaço e dos papéis dos participantes envolvidos, o debate Prós e Contras surge assim como um espaço de "realização da democracia directa, ou do seu mito" (Charaudeau/Ghiglione 2000: 148), na medida em que é palco de uma teatralização, simulando a ágora, a praça pública onde povo e governantes discutem, cara a cara, os assuntos da actualidade nacional, em situação de 
igualdade aparente. A mediatização televisiva do debate e a sua difusão em directo para milhões de telespectadores levam esta encenação democrática a casa dos portugueses, convidando-os a participarem nela, quer assistindo ao programa, quer enviando as suas opiniões via $s m s^{26}$. O debate Prós e Contras cumpre desta maneira os ideais do exercício da democracia, convocando e reunindo todos seus membros, não apenas confinada aos limites do parlamento, mas estendendo o parlamento às fronteiras nacionais.

Prós e Contras desempenha, portanto, objectivos variados que podem resumir-se nos seguintes tópicos:

- Esclarecimento da sociedade civil acerca das políticas tomadas pelos governantes que elegeu;

- Ponto de intersecção e de articulação entre os vários elementos que compõem o estado democrático (governantes, oposição, cidadãos);

- Discussão dos grandes temas da actualidade nacional;

- Publicitação perante os representantes do governo presentes de casos representativos; de dramas colectivos trazidos a estúdio sob a forma de testemunhos;

- Oportunidade de avaliação do desempenho da política do governo;

- Instrumento de divulgação ideológico-política e de persuasão.

Os objectivos em cima explanados subjacentes ao debate televisivo vão, na verdade, de encontro ao papel que os media, em geral, desempenham na construção daquilo que Charaudeau/Ghiglione designam (2000: 70) por "palavra da controvérsia", tipo de discurso que representa o imaginário da democracia:

Palavra de controvérsia: que consiste em confrontar dois ou vários pontos de vista sobre uma questão colocada em debate, com o intuito de esclarecer diversos aspectos da questão tratada (fazendo emergir verdades parciais), de maneira que os espectadores possam construir a sua própria verdade através de um acto de deliberação. Este tipo de discurso é o que justifica o imaginário da democracia [itálicos nossos].

\footnotetext{
${ }^{26}$ A participação dos telespectadores manifesta-se de duas maneiras ao longo do debate: através de comentários que enviam via sms para o programa e que passam continuamente em rodapé no écran de televisão; ou através de um voto sim ou não como resposta à questão lançada no início do programa “2003 vai ser um ano bom ou mau para Portugal?" e que pretende reflectir as expectativas dos portugueses em relação ao ano que se avizinhava. Os resultados desta sondagem eram continuamente exibidos num écran no estúdio e revelados ao fim de cada parte pela moderadora.
} 
Restará, assim referir talvez o mais importante objectivo deste debate: funcionar como ponto de ancoragem para a construção da verdade por parte de cada cidadão português.

\subsubsection{Os participantes ou o "quadro participativo" de Prós e Contras}

O programa Prós e Contras em análise apresenta um quadro participativo constituído por uma moderadora (a jornalista Fátima Campos Ferreira [FCF]), por dois painéis de participantes no debate (constituídos por três intervenientes em cada ala), ideológica e politicamente oponentes, e que representam respectivamente os sectores pró $(\mathrm{P})$ e contra ( $\left.\mathrm{P}^{\prime}\right)$ em relação a uma determinada questão, por vários elementos do público presente na audiência, que são convidados pela moderadora a dar o seu testemunho, por três convidados especiais directores de jornais (a negrito na figura em baixo), e pelo público espectador no estúdio e telespectador em casa. Temos assim uma estrutura de polílogo, na medida em que existe um sector do público que participa na interacção (veja-se Figura 6).

Fazem parte do painel Pró os seguintes convidados representativos da facção ideológica do governo em exercício: Pacheco Pereira [PP], Rui Rio [RR] e Medina Carreira [MC].

Compõem o painel Contra os seguintes participantes representativos da oposição: Manuel Maria Carrilho [MMC], Fernando Rosas [FR] e Ruben de Carvalho [RC].

Pela função e estatuto social que assumem, é possível atribuir aos seis participantes de ambos os painéis o estatuto do "político", no que respeita ao papel desempenhado no debate, segundo a definição proposta por Charaudeau/Ghiglione (2000: 58): "Político, estatuto do qual se espera que seja produzida uma «palavra empenhada» a respeito da governação da Nação (...)"

Moderadora

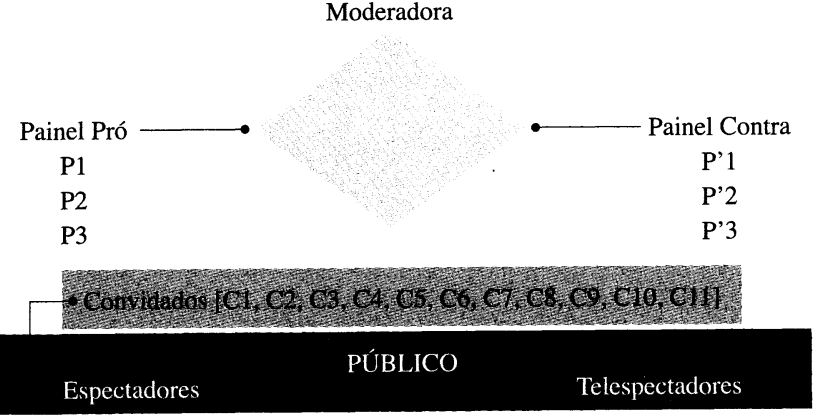

Figura 6: Quadro participativo do debate televisivo Prós e Contras. 
O confronto de ideias antagónicas, próprio do debate, decorre assim da oposição partidária e ideológica entre os dois painéis, na medida em que, no painel Pró, estão os representantes do partido do governo PSD em exercício (com excepção de Medina Carreira, que é independente), e no painel Contra os representantes dos principais partidos da oposição, designadamente o Partido Socialista (com Manuel M. Carrilho), o Bloco de Esquerda (com Fernado Rosas) e o Partido Comunista Português (com Ruben de Carvalho). Pelo seu estatuto de políticos foram convocados para participarem neste debate público, o que lhes confere o estatuto discursivo de "débateurs" no plano da interacção verbal do debate.

Formam o grupo dos directores de jornais, que também possuem o estatuto de "débateurs", os seguintes convidados especiais: Inês Serra Lopes [ISL], Sérgio Figueiredo [SF] e José Manuel Fernandes [JMF].

Estes participantes, cuja presença é assinalada pela moderadora como excepcional, participam no debate com o estatuto de vozes da autoridade, ou de "especialistas" na designação de Charaudeau/Ghiglione (2000: 599: "Especialista, estatuto do qual se espera uma «palavra sábia» e que tem o poder de explicar os fenómenos do mundo ou da sociedade".

A sua especialização em matéria de política nacional decorre, não do exercício da actividade política, à semelhança dos elementos dos dois painéis Pró e Contra, mas antes da sua profissão de jornalistas e de directores de jornais, o que os coloca numa posição privilegiada de opinion makers por serem os responsáveis pelos conteúdos e pelos moldes de difusão da informação. O papel de opinion maker é, além disso legitimado pelo estatuto de comentadores políticos que muitas vezes assumem, seja nas colunas de opinião dos jornais que dirigem, seja em programas televisivos para que são convidados.

Integram-se no grupo dos cidadãos entrevistados, da vox populi, representativo da sociedade civil os seguintes elementos, por ordem de intervenção ao longo do programa: Inna Kozyar [IK], José Manuel Pereira [JMP], Lourença Barrento [LB], Margarida Silva [MS], Carlos Fontinha [CF], Luís Sousa [LS], Rosário Fontinha [LS] e João Carreira [JC].

Estes participantes do programa não intervêm, porém, no debate propriamente dito, embora os seus testemunhos tenham uma função muito evidente de influenciar o curso do debate, enquanto exemplos de vida, enquanto alvos da aplicação das políticas ditadas pelos políticos representados em ambos os painéis. A sua participação enunciativa é paralela ao debate e articula-se com este sob forma de entrevista, quando postos em interacção com a moderadora, que assume nestes momentos a função de entrevistadora. Pela sua localização no espaço do debate (a plateia), assumem o estatuto de representantes do público, de voz do Povo, do "cidadão", ou 
do "senhor fulano", segundo a definição de Charaudeau/Ghiglione (2000: 59), ao contribuírem com o seu testemunho vivencial:

Cidadão, anónimo, do qual se espera uma «palavra de testemunho» sobre os problemas de cidadania. A senhora e o senhor fulano, outro anónimo do qual se espera igualmente uma «palavra de testemunho», mas desta vez relativamente ao papel (vítima, beneficiário, acusador, etc.) que ela/ela viveu e da razão por que foi convidada(o) [itálicos nossos].

Outra categoria de participantes é o público constituído por:

- a audiência de espectadores que assistem ao debate em estúdio e que intervêm com aplausos e outras manifestações não verbais, como risos, gargalhadas e vaias;

- a massa anónima de telespectadores que em casa assiste ao programa e que também nele participa sob a forma de mensagens escritas por telemóvel ou através do seu contributo para a sondagem televisiva.

O público é, como já foi notado antes, o destinatário último e principal de todos os discursos proferidos pelos "débateurs", o alvo que se pretende convencer e para quem se destinam verdadeiramente todas as manobras argumentativas dos políticos. De acordo com o objectivo e o assunto tratados, diferentes sectores deste público são seleccionados como destinatários, ora o grupo dos desempregados, ora o grupo dos estudantes e dos jovens, ora o grupo dos contribuintes, etc. Como demonstra Amossy (2000: 56-59), a construção da imagem do auditório é também uma estratégia argumentativa.

Finalmente, todas as intervenções dos participantes de Prós e Contras são articuladas pela moderadora, eixo estruturante de todo o programa, que assume duas funções fundamentais, de acordo com a taxonomia proposta por Charaudeau/Ghiglione (2000: 60-619:

- a função de "entrevistadora", quando entrevista os convidados do público:

o entrevistador: o animador coloca perguntas directas que podem pôr em causa não somente a opinião do entrevistado, mas também a sua forma de responder. Deve provar que ele próprio está bem documentado para revelar uma certa credibilidade junto do telespectador [itálicos nossos].

- a função de "provocadora", ao longo da gestão do debate propriamente dito, desempenhando se não todas, pelo menos as tarefas relacionadas com o desenrolar do debate propriamente dito, descritas pelos autores: 
o provocador: o representante da instância mediática é muito activo, tanto a montante, na preparação do debate (escolha dos convidados, disposição no estúdio, plano de realização), como ainda no próprio debate. Desempenha aqui um verdadeiro papel de animador, apresentando os convidados, gerindo a seu bel-prazer o tempo de intervenção de cada um, distribuindo a palavra, retirando-a ou atribuindo-a segundo a sua própria vontade, provocando uns e outros, moderando os conflitos, mantendo o controlo dos temas que vão ser tratados e permitindo-se mesmo dar a sua opinião pessoal (...) [itálicos nossos].

Damos como exemplo da função de entrevistadora a sequência que se segue, em que a moderadora revela estar bem documentada a respeito das experiências do seu convidado:

FCF: mas há alguns exemplos $(),\left({ }^{\circ}\right)$ a: no país $(),\left({ }^{\circ}\right)$ que nos dão coragem $(),(')$ que nos dão estímulo (,)(-) que nos dão confiança(,)(-) para continuarmos e sobretudo que nos dão determinação para existirmos como povo $(),($ ') e nação independente (..)(.) a: margarida, não é(?) margarida (,)(') margarida silva (..)(.) tem (,)(-) quantos anos (,)(?)

MS: dezoito

FCF: dezoito (') anos (..)(') é estudante do primeiro ano do curso de engenharia biomédica (..)(') e recebeu (') um prémio de ciência internacional (,)(.) um prémio de investigação (..)(.) a margarida está certamente orgulhosa (..)(.) [aplausos] $\{\mathrm{T} 14,0: 17-0: 48\}$

A moderadora polariza a questão que serve de tema para o programa desde o início: "2003 vai ser um ano bom ou mau para Portugal?". Ao longo do debate, a moderadora vai oscilando entre os dois pólos: o pólo Pró, dos optimistas que acreditam que 2003 vai ser um ano bom; e o pólo Contra, dos pessimistas que acham que 2003 vai ser um ano mau. O seu objectivo é o de provocar sempre o interlocutor, embora haja momentos em que deixa escapar que está do lado dos pessimistas, através de exclamações de surpresa, como no balanço final da sondagem:

FCF: ena, antes então das conclusões finais vamos aqui olhar para o gráfico (,)(.) estamos melhor que os brasileiros(,)(') mais optimistas que os brasileiros depois da da tomada de posse do presidente Lula (..)(!) dois mil e três vai ser um ano bom ou mau para portugal (, setenta e um por cento segundo esta consulta, lançada pelo programa prós e contras, setenta e um por cento acha que vai ser um bom ano. mas vinte e nove por cento e decresceu acha que não que vai ser um mau ano (..)(.) $\{$ T32, 2:00-2:26\}

Segue outro exemplo de provocação, em que a moderadora incentiva Medina Carreira a intervir, interrompendo mesmo Fernando Rosas: 
FR: [....]agora o que o estado tem depende da política tributária que segue (..)(!) porqué que o estado

FCF: política tributária (..)(') doutor medina carreira (..)(!) isto é consi$g o(.).(!)\{\mathrm{T} 30,0: 04-0: 13\}$

O excerto seguinte é outro exemplo da subjectividade discursiva da moderadora, que acaba por emitir a sua opinião comentando uma afirmação de Rui Rio, em evidente crítica ao orçamento destinado às autarquias em Portugal:

RR: [....]as autarquias não são uma ilha na administração pública portuguesa (,)(') fazem parte de um todo XXX

FCF: eu diria que são um grande arquipélago (..)(')(!)

RR: de uma cultura e de uma mentalidade e portanto [...] \{T24, 0:00-0:07\}

Como vimos na Figura 5, a par da configuração espacial evocativa do salão-teatro, visando um efeito de forum latino onde se discutiam os assuntos públicos, o programa Prós e Contras institui-se como espaço de exercício da democracia directa, traduzida na função de cada um dos elementos que compõem o seu quadro participativo.

\section{Conclusões}

Em conclusão, podemos dizer que o debate político televisivo constitui claramente um sub-tipo ou sub-género de interacção verbal, dada a sua natureza dialogal, que pode ser caracterizado pelo seu carácter organizado e em que se observa um confronto de opiniões, daí decorrendo a sua dimensão argumentativa.

Além disso, o debate político televisivo apresenta um quadro comunicativo específico, em que devem ser consideradas as coordenadas espácio-temporais (com destaque para a correlação entre a disposição espacial do seu quadro participativo e o valor simbólico desempenhado por cada um dos seus elementos, representando o exercício do ideal democrático), o formato pré-estabelecido a que obedece e os pontos em que se afasta desse formato ritualizado, os seus objectivos comunicativos (em que sublinhamos o objectivo de constituir o ponto de articulação entre os cidadãos e os seus governantes) e de estrutura participativa pré-fixada (composto por um moderador, participantes em oposição, e um público que se pretende convencer).

A dimensão política deste tipo de interacção verbal é veiculada pelo tema e estatuto socio-económico dos seus locutores. A dimensão argumentativa inerente ao dissenso subjacente ao conceito de debate conduz ao carácter polémico que também caracteriza este género. 
Pela sua dimensão televisiva e, portanto, altamente mediática, esta variante de debate público parece ser uma importante arma de manipulação da opinião pública, o que poderá explicar a sua proliferação nas grelhas programáticas dos principais canais de televisão nacionais. Esse carácter mediático intensifica-se quando o debate é transmitido em directo, como acontece no programa que serve de base de estudo a este trabalho, o que provoca uma maior tensão e responsabilidade sobre o que é dito pelos participantes do debate, dando relevo ao papel do moderador como agente que disciplina e gere os tempos e as intervenções dos participantes, entre outras dimensões ou funções.

Da análise de Prós e Contras, foi antes de mais importante perceber que o sub-tipo do debate constitui a espinha dorsal do programa, mas que o formato do programa é algo distinto e ritualizado, que obedece antes de mais a leis televisivas e publicitárias, impondo portanto uma divisão do programa em partes, intercaladas por intervalos. Assim, o programa Prós e Contras é composto por outros tipos de interacção verbal (como a entrevista) e por outros tipos discursivos (mini-reportagem audio-visual, mensagens via sms), embora todos esses discursos estejam ao serviço do debate, como agentes polemizadores. O debate é, assim, espaço de cruzamento de vários discursos, ainda que sejam privilegiadas as dimensões dialogal e argumentativa.

\section{Referências bibliográficas}

Adam, J. M. (1992): Les Textes, types et prototypes (Paris: Nathan).

Adam, J. M. (1998): "Les genres du discours épistolaire. De la réthorique à l'analyse pragmatique des pratiques discursives", em Siess, J. (org.): La Lettre entre réel et fiction: 37-53 (Caen: Editions SEDES).

Amossy, R. (2000): L'argumentation dans le discours. Discours politique, littérature d'ideés, fiction (Paris: Nathan).

Bakhtine, M. (1984): Esthétique de la création verbale (Paris: Gallimard).

Benveniste, E. (1970): "L'appareil formel de l'énonciation", Langages, 217: 12-18

Bourdieu, P. (1996, 1997): Sobre a televisão (Oeiras: Celta).

Breton, P. (1996): A Argumentação na Comunicação (Lisboa: Publicações Dom Quixote).

Bronckart, J.-P. (1985): Le fonctionnement des discours (Paris : Delachaux et Niestlé).

Brown, P. / Fraser, C. (1979): "Speech as a marker of situation", en Scherer, K. R. I Giles, H. (eds.), Social markers in speech: 33-62 (Cambridge, England: Cambridge University Press).

Charaudeau, P./ Ghiglione, R. (1997): A palavra confiscada. Um género televisivo: o talk show (Lisboa: Instituto Piaget).

Coutinho, M. A. (2003): Textos e Competência Textual (Lisboa: Fundação Calouste Gulbenkian / Fundação para a Ciência e Tecnologia). 
Doury, M. (1995): “Duel sur la Cinq : Dilogue ou Trilogue?”, em Plantin, C. / KerbratOrecchioni (eds.), Le Trilogue: 224-249 (Lyon: Presses Universitaires de Lyon).

Ducrot, O. (1980): Les Échelles Argumentatives (Paris: Minuit).

Ducrot, O. (1984): Le dire et le dit (Paris: Minuit).

Fonseca, J. (1992): Linguística e Texto/Discurso - Teoria, Descrição, Aplicação (Lisboa: ICALP).

Fonseca, J. (1994): Pragmática Linguística. Introdução, Teoria e Descrição do Português (Porto: Porto Editora).

Fuentes Rodrígues, C. (2000): Lingüística pragmática y análisis del discurso (Madrid: Arco / Libros).

Goffman, E. (1981): Forms of Talk (Phyladelphia: University of Pennsylvania Press).

Herrero Moreno, G. (2001): "El discurso polémico: el desacuerdo y los actos disentivos", em Bustos, J. J. de / Charadeau, P. / Girón, J. L. / Iglesias, S. / López Alonso, C. (coords.), Lengua, discurso, texto. I simposio internacional de análisis del discurso. Vol. I: 1583-1594 (Madrid: Visor Libros)

Jakobson, R. (1960): "Linguística e Poética", en Linguística e Comunicação (S. Paulo: Cultrix).

Kallmeyer, W. / Schütze, F. (1976): "Konversationsanalyse”, em Studium Linguistik, 1: $1-28$.

Kerbrat-Orecchioni, C. (1990): Les interactions verbales 1. Approche interactionnelle et structure des conversations (Paris: Armand Colin).

Kerbrat-Orecchioni, C. (1999): L'énonciation. De la subjectivité dans le langage (Paris: Armand Colin).

Marques, M. A. (2003): "Renovação dos Discursos - Novas Formas de Interacção e Legitimação dos Interlocutores", Diacrítica, Ciências da Linguagem, 17-1: 189-219.

Marques, M. E. R. (1988): A complementação verbal. Estudo sociolinguístico. Tese de Doutoramento (inédita). Universidade Nova de Lisboa. Faculdade de Ciências Sociais e Humanas.

Pires, A. P. (2002): Estratégias Discursivas de Marcação da Diferença no Debate Político Televisivo. Dissertação de Mestrado (inédita). Instituto de Letras e Ciências Humanas da Universidade do Minho.

Plantin, Ch. (1996): L'argumentation (Paris: Seuil).

Rodrigues, I. M. G. (1998): Sinais conversacionais de alternância de vez (Porto: Granito).

Sarfati, G-E. (1997): Éléments d'Analyse du Discours (Paris: Nathan Université).

Vion, R. (1992): La communication verbale. Analyse des interactions (Paris: Hachette). 


\section{Anexo: Lista dos participantes no debate Prós e Contras}

\begin{tabular}{l|ll}
\multicolumn{1}{c|}{ Nome } & Sigla & $\begin{array}{c}\text { Estatuto dentro do } \\
\text { quadro participativo }\end{array}$ \\
\hline Fátima Campos Ferreira & FCF & Moderadora \\
\hline Pacheco Pereira & PP & Participante Painel Pró \\
Manuel Maria Carrilho & MMC & Participante Painel Contra \\
Rui Rio & RR & Participante Painel Pró \\
Fernando Rosas & FR & Participante Painel Contra \\
Medina Carreira & MC & Participante Painel Pró \\
Ruben de Carvalho & RC & Participante Painel Contra \\
Inês Serra Lopes & ISL & Convidada Especial 1 \\
Sérgio Figueiredo & SF & Convidado Especial 2 \\
José Manuel Fernandes & JMF & Convidado Especial 3 \\
\hline
\end{tabular}

